\title{
Information-Seeking Habits of Education Faculty
}

\section{Karen Rupp-Serrano and Sarah Robbins}

\begin{abstract}
This study explores the information-seeking behavior of academic education faculty from twenty large public research universities. The investigation includes an examination of how frequently education faculty seek or access information, how they stay up-to-date on current developments in the field and identify less recent journal literature, how valuable library resources and services are to their information needs, and the importance of library research to the field of education. The responses from the survey participants emphasize the importance of electronic access to scholarly journals and library databases and the continuing value of books, both print and electronic, for meeting the information and research needs of education faculty.
\end{abstract}

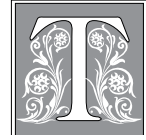

he information-seeking habits and information needs of faculty are of interest and importance to academic librarians. Knowing the information that is desired by faculty, for what purposes, and how it is discovered, can guide an array of academic library services, policies, programmatic offerings, and collection development activities. To this end, studies of faculty in a range of disciplines have been conducted, from engineering and chemistry to social work and art. No studies, however, have been conducted primarily on education faculty. Noting this, the authors set out to learn more about the information-seeking behaviors of education faculty in an effort to begin addressing this gap in the literature.

This article seeks to address some aspects of the information-seeking behavior and information needs of education faculty. The researchers explored what tools faculty use to meet their research needs, how frequently information is sought, in what ways currency in the field of education is maintained, and the importance of library resources and services in meeting the information needs of faculty. The article is the second in a series of articles designed to gather data on information-seeking behaviors of faculty in the disciplines.

\section{Review of Literature}

Education is a social science discipline as well as a profession. In this respect, it is similar to a handful of other social science disciplines such as social work, public administration, and library science. Professional disciplines seek knowledge for its own sake but also for practical application. Wright notes that, similar to other social science disciplines, within education there is a "lack of consensus on the nature, execution and application

Karen Rupp-Serrano is Director of Collection Development $\mathcal{E}$ Scholarly Communication and Sarah Robbins is Director of Public Relations E Strategic Initiatives, both at University of Oklahoma Libraries; e-mail: krs@ ou.edu, srobbins@ou.edu. (C) 2013 Karen Rupp-Serrano and Sarah Robbins, Attribution-NonCommercial (http://creativecommons.org/licenses/by-nc/3.0/) CC BY-NC 
of...research" and goes on to state that there is a "fundamental disconnect between scholars and practitioners" within the field. ${ }^{1}$

Educational research is multidisciplinary, drawing from other social sciences, including psychology, linguistics, and sociology. The conduct of educational research can vary widely, reflecting the needs of numerous subfields, from history of education to kinesiology, counseling to curriculum design. Education uses a variety of research methodologies common to the social sciences, both quantitative and qualitative, and is a strong proponent of action research. Action research focuses on practical problems in an effort to "take action" to solve a problem or improve a situation and is not intended to be generalized beyond the immediate context in which it occurs. ${ }^{2}$

An understanding of the many facets of the education discipline is essential to understanding the information-seeking behavior of the discipline and a first step toward providing quality library services to the discipline. While there have been no studies conducted with a primary focus on faculty in the field of education, there have been a number of studies focusing on the broad categories of the sciences, humanities, and social sciences.

One of the most influential studies focusing on the social sciences was Line's 1971 INFROSS study, which occurred well before the advent of the extensive online resources now available. ${ }^{3}$ Line found that, within the social sciences, individuals more frequently used nonsystemic ways to keep abreast of current research. Social scientists tended to rely on personal collections and communication networks and informal information channels more than formal collections such as libraries. Those in the social sciences placed a great deal of importance on journal literature and frequently identified sources by following citations but did not refer much to catalogs, librarians, or indexes. Both Baxter ${ }^{4}$ and Folster ${ }^{5}$ confirmed this finding.

Patricia Davitt Maughan ${ }^{6}$ found, in her
1999 study of select UC-Berkeley faculty in the sciences, social sciences (represented by political science), humanities, professional, and interdisciplinary studies, that a majority of social scientists reported browsing, consulting with a librarian, using the online catalog, referring students, and remotely using online resources other than the catalog "sometimes" or "often." An extensive 2002 review of the literature on scholarly communication and bibliometrics by Borgman and Furner ${ }^{7}$ found that the social sciences tend to seek information from journals, books, and other resources for their publications. This behavior puts them somewhere between the sciences, which tend to use recent journal literature, and the humanities, which tend to heavily use books, both old and new.

An important work of the last decade, Dimensions and Use of the Scholarly Information Environment, was underwritten by the Digital Library Federation and the Council on Library and Information Resources. ${ }^{8}$ This report noted that faculty in liberal arts, humanities, biological sciences, and law seemed to use the library more than other disciplines. Faculty and students alike seemed prone to a hybrid environment using information in both print and electronic formats. Budd and Christensen, ${ }^{9}$ in their study on social sciences literature and electronic information, confirmed Borgman and Furner's findings. Furthermore, they demonstrated that the age of literature used in the social sciences tended to fall between the sciences and humanities, with a range of 1-35 years and a mean age of 11.77 years.

In 2003, Abouserie $^{10}$ conducted a field study of information-seeking and communication behavior, particularly in regard to electronic journals, among social science faculty in an academic environment. This study included education faculty. He found that search engines were the most used type of information resource among education faculty, double that of any other resource category. Interestingly, print journals led the second tier of information resource 
use among education faculty, although it came in only slightly ahead of electronic journals. Traditional sources (defined as books, references, and reports in the university library system) were least used by education faculty (compared to other kinds of sources) and were the least used by education faculty in comparison with social sciences faculty in law, public and international affairs, and social work. Also in 2003, the research by Palmer and Sandler ${ }^{11}$ showed a strong majority within the electronic materials preferred in the social sciences. Interestingly, they found that social scientists reported they desired assistance from librarians to keep up with the rapid pace of change.

In 2009, Ithaka $S+R^{12}$ confirmed that the humanities and social sciences continued to use the library building and catalog more than the sciences did, but that use has dropped steadily since the initial Ithaka study in 2003. This study also documented a development in the preference for information formats. Faculty responses within the study demonstrated that a significant change has occurred for journals, with the strong majority of faculty willing to access current journals in electronic format only. Over 70 percent of social scientists strongly agreed with this statement: "If my library cancelled the current issues of a print version of a journal but continued to make them available electronically, that would be fine with me."

Wang $^{13}$ reported in 2010 on information seeking and use of scholarly journals among social scientists at a Taiwanese university, including education faculty members. Specific to education faculty, Wang found that digital communication channels such as database searching, e-mail, and electronic journal use were most common in the College of Education in comparison to faculty members in the College of Social Sciences and the College of Law. The main research output of the College of Education faculty was journal articles, and electronic journals were the preferred journal format for them.

\section{Methodology}

For the current study, the researchers surveyed education faculty members from twenty large public research institutions across the United States using a 15-item survey. Designed to take just a few minutes to complete, the survey instrument gathered qualitative and quantitative data. The survey followed a format similar to that used by Robbins, Engel, and Kulp to provide matching data points for a companion article on the generalizability of findings of single institution studies. ${ }^{14}$ The authors requested feedback on the survey from several education faculty members prior to sending it out. Survey responses were anonymous and confidential; respondents were not required to answer every question. An e-mail invitation to participate in the survey was sent in October 2010 to approximately 2,878 education faculty members at the selected research institutions. The institutions were selected as a purposive sample, representing different regions of the United States, each a member of the Association of Research Libraries with a top-rated education program according to U.S. News \& World Report. ${ }^{15}$ E-mail addresses for all education faculty listed on the institutions' websites were gathered by student assistants, including those for tenured and nontenured faculty, researchers and emeritus faculty, adjuncts, instructors, and lecturers; institutions without an easily accessible website listing of faculty at the time of data collection were not surveyed. Faculty members were given three weeks to respond, and a reminder e-mail was sent after two weeks.

\section{Results}

\section{Respondents}

Of the 2,878 e-mail invitations sent, 538 responses were received, for a response rate of 18.7 percent. A majority of respondents were professors $(26 \%)$, associate professors $(25 \%)$, or assistant professors (23\%). Of the remainder, 13 percent were ranked as adjunct faculty, instructors, 
lecturers, or professors emeriti, and 13 percent selected "other." A majority of respondents selecting "other" indicated theirs was a research, administrative, or clinical appointment. A total of 38 percent of the education respondents had been in their position for sixteen years or longer, followed by 27 percent who had held their position for five years or less, 19 percent who had been in their position from six to ten years, and 16 percent who had held their position for eleven to fifteen years. Over 50 percent of the survey respondents had been in their positions for more than eleven years.

Faculty members were asked to select the branch of education that most closely aligned with their area of emphasis. The "other" category received the highest percentage of responses at 24 percent, a testimony to the variety present in colleges of education. Health/exercise science/kinesiology, counseling psychology, and math/science education were the responses most frequently listed for "other." Of the remaining educational areas listed in the question, most were in teacher education (20\%), educational psychology $(13 \%)$, special education $(11 \%)$, or higher education $(8 \%)$. A potential limitation of this study is the lack of representation of certain subfields within education, such as educational policy, educational administration, or educational measurement/evaluation.

\section{Meeting Research Needs}

Respondents were asked how important ten resource categories were to helping them with their research: scholarly journals (print or online), Internet resources, books, textbooks, attendance at conferences, e-mail discussion with colleagues, face-to-face discussion with colleagues, e-mail discussion with students, face-toface discussion with students, or other. Scholarly journals, Internet resources, books, and face-to-face discussions with colleagues were the most important resources in assisting education faculty with their research (see figure 1), with scholarly journals being the top resource at 89 percent; Internet resources were second at 57 percent. The third most important resource was books at 46 percent, and the fourth ranked resource was face-to-face discussions with colleagues, at 42 percent.

As a corollary to this question, respondents were asked how important library research is to the field of education. Good news for libraries: the responses indicated that 57 percent of respondents view library research as very important, and 31 percent view it as important. Thus, for 88 percent of respondents, library research is clearly a key component in the field of education.

\section{Frequency of Information Seeking and/or Accessing Information}

Respondents were asked to indicate how frequently they accessed or searched for

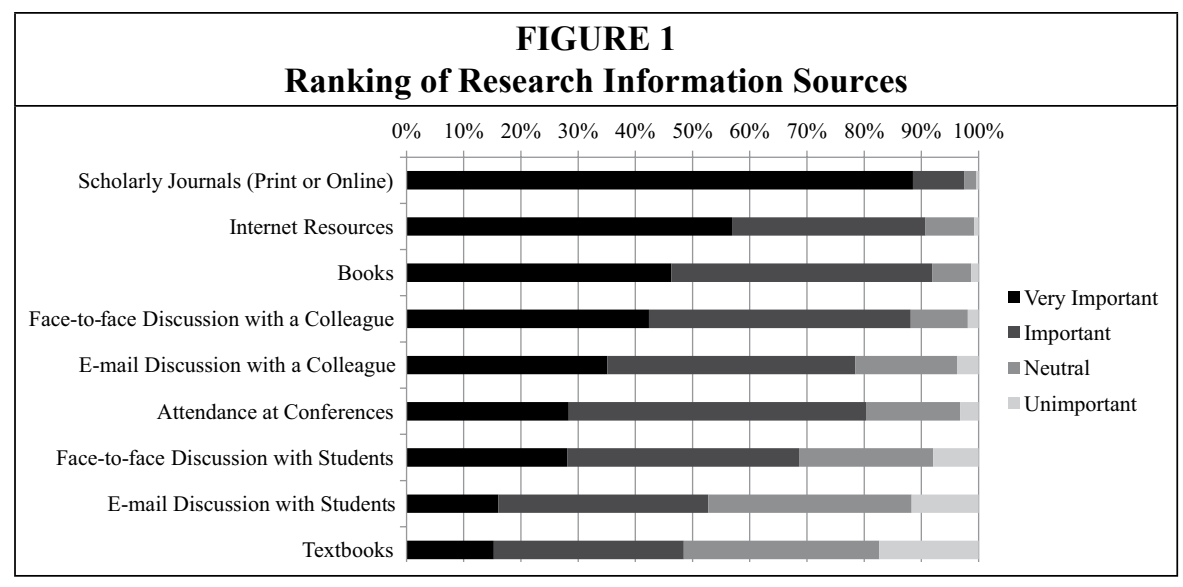




\begin{tabular}{|l|c|c|c|c|c|c|}
\hline \multicolumn{7}{|c|}{ TABLE 1 } \\
\hline Frequency of Seeking or Accessing Information to Complete Tasks \\
\hline Tasks & Daily & Weekly & Monthly & $\begin{array}{c}\mathbf{1 - 2 /} \\
\text { Semester }\end{array}$ & Annually & N/A \\
\hline Prepare for Student Lectures & $23 \%$ & $55 \%$ & $7 \%$ & $5 \%$ & $1 \%$ & $9 \%$ \\
\hline $\begin{array}{l}\text { Professional Development/ } \\
\text { Remain Current in the Field }\end{array}$ & $25 \%$ & $34 \%$ & $21 \%$ & $12 \%$ & $6 \%$ & $2 \%$ \\
\hline $\begin{array}{l}\text { Write/Research for } \\
\text { Publication }\end{array}$ & $20 \%$ & $35 \%$ & $16 \%$ & $12 \%$ & $7 \%$ & $10 \%$ \\
\hline $\begin{array}{l}\text { Prepare for a Conference } \\
\text { Presentation }\end{array}$ & $5 \%$ & $12 \%$ & $26 \%$ & $41 \%$ & $11 \%$ & $5 \%$ \\
\hline $\begin{array}{l}\text { Prepare Research or Grant } \\
\text { Proposal }\end{array}$ & $4 \%$ & $7 \%$ & $16 \%$ & $28 \%$ & $29 \%$ & $16 \%$ \\
\hline $\begin{array}{l}\text { Determine Protocols for } \\
\text { Research }\end{array}$ & $2 \%$ & $10 \%$ & $18 \%$ & $29 \%$ & $18 \%$ & $23 \%$ \\
\hline
\end{tabular}

information to complete several tasks: prepare for student lectures; prepare for conference presentations; determine protocols for research; research or write for publication; prepare a research proposal or grant application; and remain current in their field or develop professionally. Options provided were daily, weekly, monthly, once or twice per semester, annually, or not applicable (see table 1).

On at least a weekly basis, 79 percent of survey respondents accessed or sought information to prepare student lectures, 59 percent to remain current within their field, and 55 percent to write or research for publication. At least once or twice per semester, 52 percent of responding

\begin{tabular}{|c|c|}
\hline \multicolumn{2}{|c|}{$\begin{array}{c}\text { TABLE } 2 \\
\text { Tasks Included in Departmental } \\
\text { Duties of Respondents }\end{array}$} \\
\hline Tasks & $\%$ \\
\hline Graduate Instruction & $90 \%$ \\
\hline Supervision of Doctoral Research & $71 \%$ \\
\hline Grant Preparation & $69 \%$ \\
\hline Field and/or Laboratory Research & $64 \%$ \\
\hline Administrative Duties & $56 \%$ \\
\hline Undergraduate Instruction & $45 \%$ \\
\hline Other & $8 \%$ \\
\hline Commercial/Proprietary Research & $4 \%$ \\
\hline
\end{tabular}

education faculty sought or accessed information to prepare for a conference presentation, 57 percent to prepare a research proposal or grant application, and 47 percent to determine protocols for field research.

These responses mesh with the activities most commonly reported by education faculty as being included in their departmental duties (see table 2). Graduate instruction was the most common departmental duty, followed by supervision of doctoral research, grant preparation, field/laboratory research, administrative duties, and undergraduate instruction.

Delving more deeply into the research and writing aspects of the previous question, education faculty were also asked to indicate the number of grants, presentations, or patent/commercial or publication projects completed within the last five years. Responses demonstrated that refereed journal articles or book chapters are the most common publication project, followed closely by grant applications, conference proceedings, and nonrefereed journal articles or book chapters. Books are completed less frequently, and patents/commercial projects least frequently (see table 3). These findings are consistent with the literature on social science faculty. 
TABLE 3

Activities Completed Within the Past Five Years by Respondents

\begin{tabular}{|l|c|c|c|c|c|}
\hline Activities & $\mathbf{0}$ & $\mathbf{1 - 3}$ & $\mathbf{4 - 7}$ & $\mathbf{8 - 1 1}$ & $\mathbf{1 2 +}$ \\
\hline Refereed Articles/Chapters & $13 \%$ & $25 \%$ & $25 \%$ & $16 \%$ & $21 \%$ \\
\hline Grant Applications & $18 \%$ & $42 \%$ & $26 \%$ & $10 \%$ & $5 \%$ \\
\hline Conference Proceedings & $19 \%$ & $28 \%$ & $23 \%$ & $11 \%$ & $19 \%$ \\
\hline Nonrefereed Articles/Chapters & $24 \%$ & $46 \%$ & $21 \%$ & $5 \%$ & $3 \%$ \\
\hline Books & $59 \%$ & $35 \%$ & $4 \%$ & $1 \%$ & $1 \%$ \\
\hline Patents/Commercial Projects & $92 \%$ & $6 \%$ & $2 \%$ & $0 \%$ & $0 \%$ \\
\hline
\end{tabular}

\section{Keeping Current in the Education Field}

Staying abreast of current developments in one's field is an obligation in any profession. Education faculty were asked how they remain current; they were allowed to choose all of the options provided. As illustrated in table 4, respondents chose scanning current issues of journals, attending professional conferences, following references or leads from an article or item of interest, and personal communication most frequently for this purpose. Less popular tools for maintaining currency consisted of scanning recent issues of abstracting and indexing tools, electronic discussion lists, RSS feeds, and current awareness services.

As a corollary to this question, education faculty were also queried as to

\begin{tabular}{|c|c|}
\hline \multicolumn{2}{|c|}{$\begin{array}{c}\text { TABLE } 4 \\
\text { Methods of Keeping Abreast of } \\
\text { Current Developments in the Field }\end{array}$} \\
\hline Methods & $\%$ \\
\hline $\begin{array}{l}\text { Scanning Current Issues of } \\
\text { Journals }\end{array}$ & $90 \%$ \\
\hline Attendance at Conferences & $81 \%$ \\
\hline $\begin{array}{l}\text { Follow References or Leads from } \\
\text { an Article or Item }\end{array}$ & $80 \%$ \\
\hline Personal Communication & $66 \%$ \\
\hline Electronic Discussion Lists & $32 \%$ \\
\hline $\begin{array}{l}\text { Scanning Recent Issues of } \\
\text { Abstracting Indexing }\end{array}$ & $33 \%$ \\
\hline RSS Feeds & $14 \%$ \\
\hline Other & $9 \%$ \\
\hline Current Awareness Service & $4 \%$ \\
\hline
\end{tabular}

which factors most influence their use of a current information source. Again, they were allowed to choose all of the options provided. Table 5 shows that authoritativeness is far and away the leading criterion, with 53 percent of all respondents choosing this. Other criteria were, in descending order: reliably available/no wait or hassle $(16 \%)$; convenience $(11 \%)$; least time to track down (7\%); familiarity $(6 \%)$; currency $(5 \%)$, and other $(3 \%)$.

\section{Awareness of Less Recent Journal Articles}

Survey respondents were also asked how they became aware of less recent literature and were allowed to choose all of the options provided. As shown in figure 2, 93 percent of the responding education faculty used citations at the end of

\begin{tabular}{|c|c|}
\hline \multicolumn{2}{|c|}{$\begin{array}{l}\text { TABLE } 5 \\
\text { Factors Influencing Use of a } \\
\text { Current Information Source }\end{array}$} \\
\hline Influencing Factors & $\%$ \\
\hline $\begin{array}{l}\text { Authoritativeness (Reliable, } \\
\text { Complete Information) }\end{array}$ & $53 \%$ \\
\hline $\begin{array}{l}\text { Reliably Available/No Wait or } \\
\text { Hassle }\end{array}$ & $16 \%$ \\
\hline Convenience & $11 \%$ \\
\hline $\begin{array}{l}\text { Least Time to Track Down } \\
\text { the Information }\end{array}$ & $7 \%$ \\
\hline Familiarity & $6 \%$ \\
\hline Currency & $5 \%$ \\
\hline Other & $3 \%$ \\
\hline
\end{tabular}




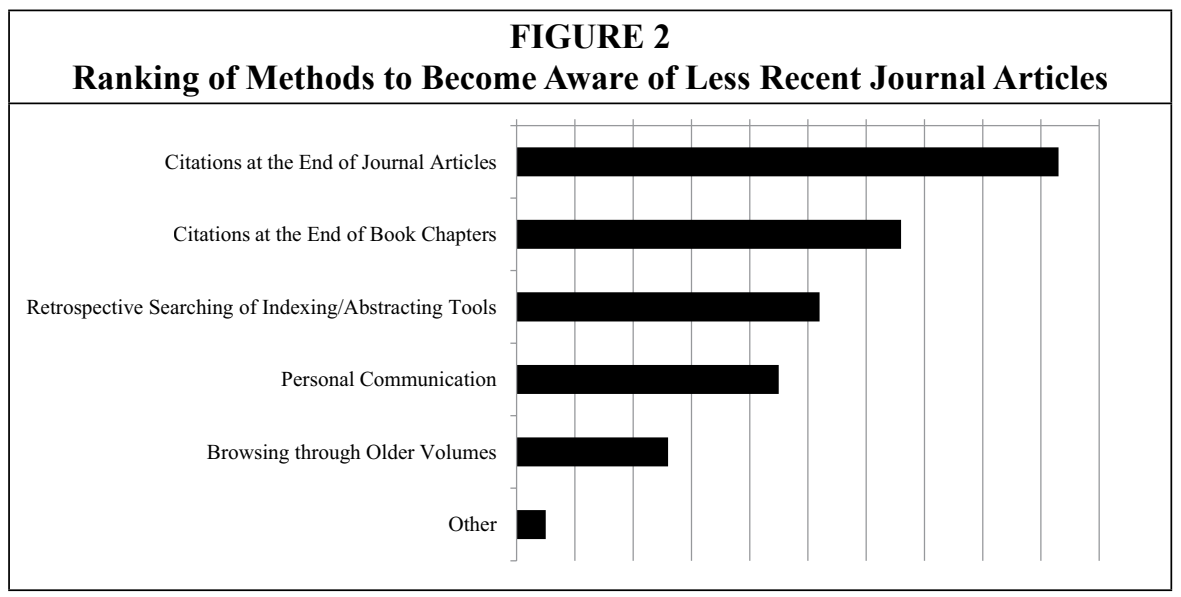

journal articles to find older material. In descending order, other options selected were citations at the end of book chapters $(66 \%)$, retrospective searching of indexing and abstracting tools (52\%), personal communication $(45 \%)$, browsing through older volumes (26\%), and "other" (5\%).

\section{Importance of Library Services and Resources}

Ten library services were rated by responding education faculty as very important, important, neutral, unimportant, or not applicable to their needs. Figure 3 illustrates that access to schol- arly electronic journals, whether current or archival, is of greatest importance. Current and archival electronic access was rated by 98 percent of respondents as very important or important. Also very important or important to survey respondents were library databases $(94 \%)$, interlibrary loan $(77 \%)$, print books and e-books (70\%), document delivery $(66 \%)$, library assistance $(61 \%)$, and print journal subscriptions (54\%). Only space to study or conduct research was ranked as neutral, unimportant, or not applicable by a majority of the respondents $(63 \%)$.

FIGURE 3

\section{Ranking of Library Resources and Services for Meeting Information Needs}

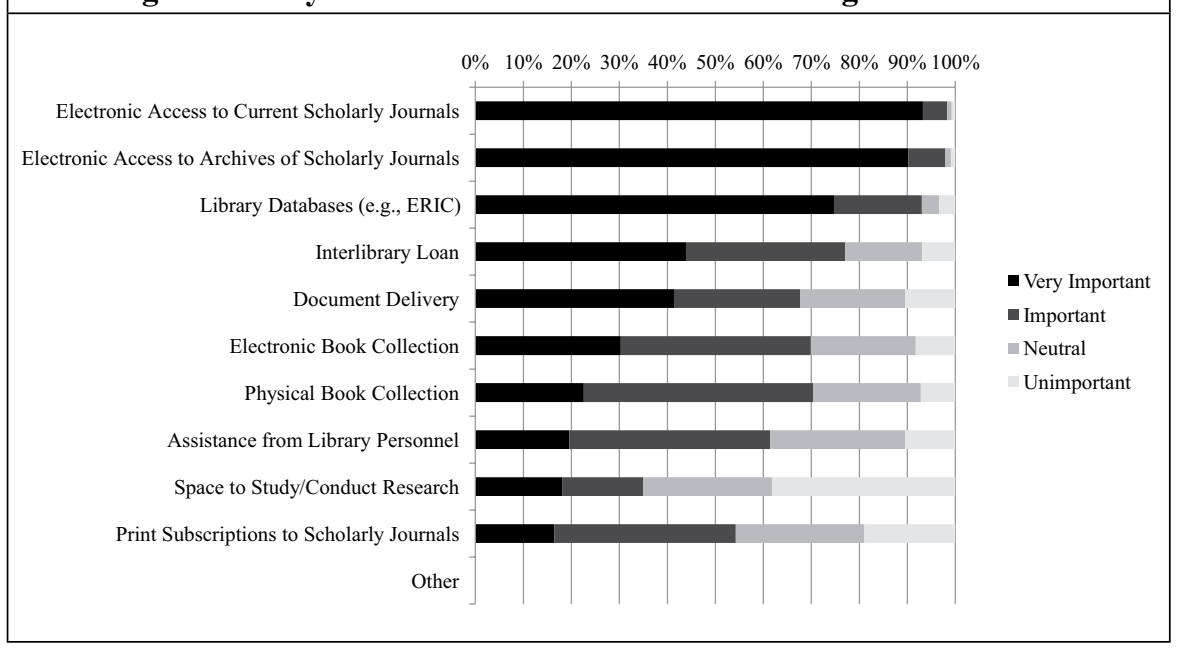




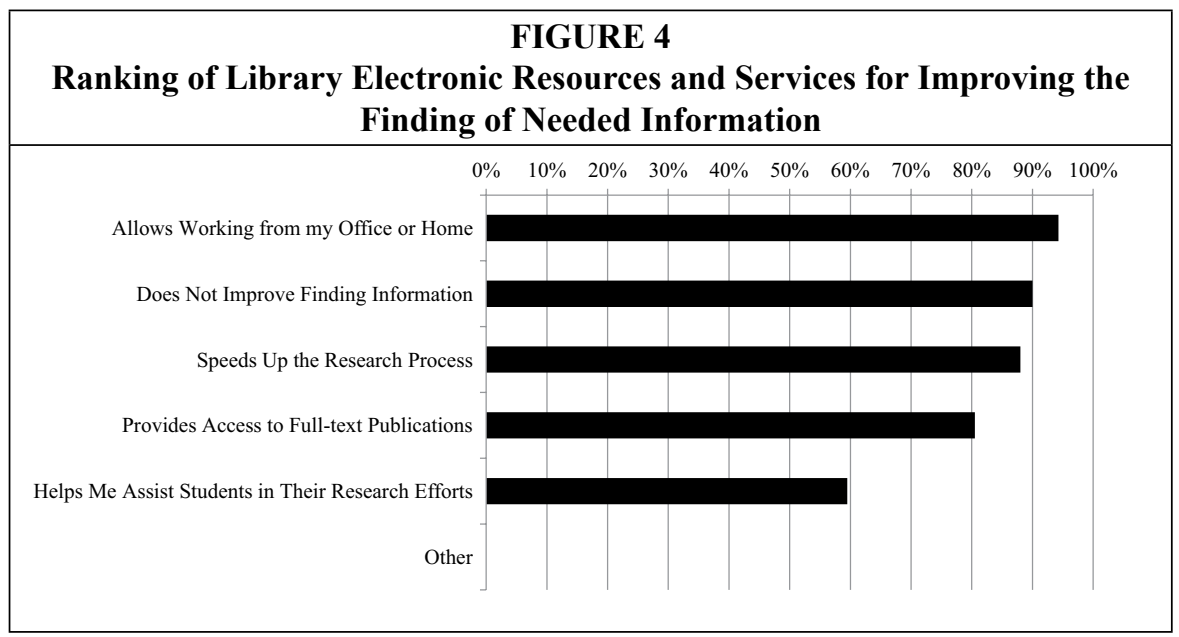

A second question about library services and resources allowed respondents to note how the library's electronic resources and services improve finding needed information; respondents were allowed to select all options that applied. Figure 4 shows that the most popular response was allowing one to work from home or office, followed by speeding up the research process, providing access to full-text publications, and helping faculty assist students in their research efforts.

A third question in this area delves into how the use of library electronic

\begin{tabular}{|l|c|}
\hline \multicolumn{2}{|c|}{ TABLE 6 } \\
\multicolumn{2}{|c|}{$\begin{array}{c}\text { Factors Limiting Use of Library } \\
\text { Electronic Services }\end{array}$} \\
\hline Limiting Factors & $\%$ \\
\hline $\begin{array}{l}\text { Unavailability of Needed } \\
\text { Electronic Resources or } \\
\text { Services }\end{array}$ & $62 \%$ \\
\hline Lack of Time & $42 \%$ \\
\hline Access Restrictions & $38 \%$ \\
\hline $\begin{array}{l}\text { Unaware of Available } \\
\text { Electronic Resources and } \\
\text { Services }\end{array}$ & $37 \%$ \\
\hline $\begin{array}{l}\text { Hard to Find on Library } \\
\text { Website }\end{array}$ & $25 \%$ \\
\hline Lack of Instructions & $18 \%$ \\
\hline Other & $5 \%$ \\
\hline
\end{tabular}

services and resources might be limited; respondents were again allowed to select all options that applied. Table 6 illustrates that the most common limiting factor was the unavailability of needed electronic resources or services; 62 percent selected this option. No library can afford everything and, of course, some items simply are not available electronically. Other limiting factors in descending order were lack of time $(42 \%)$, access restrictions $(38 \%)$, unawareness of available resources or services $(37 \%)$, hard to locate on library website $(25 \%)$, or lack of instructions $(18 \%)$.

\section{Education Faculty Narrative Comments}

An open-ended question asking education faculty whether there were services their library did not provide that would assist them in meeting their information needs was included in the survey. Most responses fell into one of three categories. The first was the need for more resources; most frequently, this was a request for additional journals or for journals in electronic format. A number of responses also requested additional e-books, which corresponds with the responses noted earlier about print books and e-books.

The second most common response was simply "no," indicating there were no services the respondent could identify in response to the question, or a statement 
of satisfaction with the library in general. The third response most commonly observed was a call for services, most often requesting more instruction or the delivery of physical items.

\section{Discussion and Conclusion}

This study includes some of the most common information-seeking behaviors and information needs of education faculty. Responses generally confirmed studies of social sciences faculty that found journal literature is of primary importance. Not only is journal literature heavily used by education faculty, it is also the foremost publication outlet of the field; this confirms Wang's finding ${ }^{16}$ that the main research output of education faculty is journal articles.

Internet resources also received strong use ratings. It is possible that some respondents considered online journals or databases as Internet resources, thus inflating the importance of that resource category. On the other hand, this may reflect a new reality, one in which the use of the Internet has grown dramatically in importance. Any future researcher should structure questions about Internet resources to avoid possible conflation of these resources, clearly separating Internet resources from online journals or databases.

Some respondents may also have interpreted Internet resources to include ERIC documents and grey literature. If a future researcher is working specifically on the field of education, one or more separate questions should address ERIC to better understand the use of this unique resource.

The importance faculty placed on current and archival access to electronic journal literature speaks to the need for libraries to market and brand the content they provide as a key means of reminding users what the library is doing for them. Turning off electronic access for a "day without libraries" is not an option, however effective it might be in making the point, so graphic branding and steady, cohesive marketing efforts must be employed.

A closer examination of the rankings of electronic and print scholarly journal subscriptions demonstrate an interesting dynamic. When considering print journal subscriptions, 54 percent of the respondents rated them very important or important, yet 46 percent of the respondents rated them neutral or unimportant. This ambivalence stands in marked contrast to the overwhelming importance faculty placed on electronic access, with 98 percent rating electronic access very important or important. The 2009 Ithaka Faculty Survey demonstrated that importance of print is waning, and this situation is not likely to reverse. ${ }^{17}$ Libraries retaining print subscriptions should investigate their local commitment closely to determine if they are maintaining those subscriptions out of habit rather than in response to a true need.

Interestingly, 94 percent of respondents indicated library databases were a very important or important library resource, but scanning recent issues of abstracting and indexing tools was not as important to education faculty in maintaining currency. Does this mean that faculty do not see library databases as sources of indexing and abstracting, that "scanning recent issues of abstracting and indexing tools" connotes using something other than online databases, or simply that, while faculty consider databases important, they are not central to maintaining currency? The authors also wonder whether faculty consider library databases as important for someone other than themselvesgraduate or undergraduate students, perhaps-but not important to how they themselves maintain currency. This is an area that future research could explore in greater depth.

Responses about print and electronic books showed that 70 percent of survey respondents felt both formats were very important or important. A closer examination of these responses showed an interesting pattern. While the same 
percentage of respondents found books, print or electronic, as important or very important $(70 \%)$, there was a larger disparity between the number of respondents who found print books very important $(32 \%)$ or important $(68 \%)$ in comparison to the number who found electronic books very important (43\%) or important $(57 \%)$. In a comparison of the two formats, a higher percentage of respondents rated electronic books very important. This could signal a rise in the importance of electronic books to the field of education. For education, a field that has been in the forefront of online pedagogy, books that can be accessed online by students whenever, wherever, are a clear need. Collection development librarians should take note and adjust their acquisitions accordingly.

Education faculty rated authoritativeness as the number one criterion most influencing their use of a current information source. This has clear implications for both collection development and library instruction. In collection development, librarians must ensure they have sufficient authoritative resources available to meet needs, are aware of database journal coverage, and regularly review journals to ascertain if they are meeting high publication standards. For library instruction, it is essential that librarians who work with education students teach them how to assess the authoritativeness of a resource, whether it is a book, an article, a video, or an Internet resource.

Instruction is not just for students, either. A number of survey respondents indicated they were unaware of electronic resources or services, felt electronic services were difficult to find on the library website, or that they lacked instruction to use electronic resources. Libraries should seek to inform faculty of library electronic resources and services through a variety of creative means. Regular usability testing to improve website layout and navigation should be conducted. Offering instruction through multiple venuesproviding point-of-need tutorials on the library website, attending departmental meetings, encouraging faculty to attend instruction sessions they schedule for their students, establishing regular office hours within academic departments or even just dropping by faculty officescould help provide those all important "teachable moments."

This study found a substantial majority $(88 \%)$ of education faculty rating library research as important or very important to their field, which does not corroborate with most studies of social science researchers other than Maughan's Berkeley study. ${ }^{18}$ Maughan found that all the selected disciplines surveyed reported using the library to do their own scholarly research sometimes or often.

Further research on education faculty could be conducted to illuminate areas in this study where questions arose. The profession could benefit from a better understanding of what constitutes an Internet resource in the minds of users. Are online journals generally considered an Internet resource? If so, does this inflate the importance of Internet resources for meeting research needs, maintaining currency, and tracking literature? The profession could also benefit from a deeper exploration of the importance of online indexing and abstracting databases based on somewhat conflicting data found in the current study. Are these resources worth what we pay for them in a world that offers Google Scholar and a host of other Internet search engines? Further research into how education faculty differ from other social sciences faculty is an ongoing need, as the literature is scanty and what we learn can assist in serving this population. 


\section{Notes}

1. Carol Wright, "Information-Seeking Behaviors of Education Literature User Populations," Teachers College Record 112, no. 10 (2010): 2537-64.

2. Donald Ary, Lucy Cheser Jacobs, Ashgar Razabieh, and Chris Sorensen. Introduction to Research in Education, 7th ed. (Belmont, Calif.: Thomson Higher Education, 2006).

3. Maurice B. Line, The Research Procedures of Social Scientists, Research Report No. 5: Investigation Into Information Requirements of the Social Sciences, INFROSS (Bath, England: Bath University Library, 1971).

4. Pam M. Baxter, "A View of Academics' Literature Search Methods: The Case of the Social Sciences and Its Implications for Students," Reference Librarian 12, no. 27/28 (1990): 419-31.

5. Mary B. Folster, "Information Seeking Patterns: Social Sciences," Reference Librarian 23, no. 49/50 (1995): 83-93.

6. Patricia Davitt Maughan, "Library Resources and Services: A Cross-Disciplinary Survey of Faculty and Graduate Student Use and Satisfaction," Journal of Academic Librarianship 25, no. 5 (1999): 354-66.

7. Christine L. Borgman and Jonathan Furner, "Scholarly Communication and Bibliometrics," Annual Review of Information Science and Technology 36 (2002): 3-72.

8. Amy Friedlander, Dimensions and Use of the Scholarly Information Environment: Introduction to a Data Set Assembled by the Digital Library Federation and Outsell, Inc. (Washington, D.C.: Digital Library Federation, Council on Library and Information Resources, 2002).

9. John M. Budd and Corrie Christensen, "Social Sciences Literature and Electronic Information," Portal: Libraries and the Academy 3, no. 4 (2003): 643-51.

10. Hossam Abouserie, "Information Seeking and Communicating Behavior of Social Science Faculty in an Academic Environment with Special Reference to the Use of Electronic Journals: A Field Study" (PhD diss., University of Pittsburgh, 2003), ProQuest (AAT 3105735).

11. Janet P. Palmer and Mark Sandler, "What Do Faculty Want?" Library Journal 128, no. 1 (2003): 26-28.

12. Roger C. Schonfeld and Ross Housewright, Faculty Survey 2009: Key Strategic Insights for Libraries, Publishers, and Societies (New York, N.Y.: Ithaka S+R, 2009); Mei-Ling Wang, "Scholarly Journal Use and Reading Behavior of Social Scientists in Taiwan," International Information and Library Review 42, no. 4 (2010): 269-81.

13. Wang, "Scholarly Journal Use and Reading Behavior of Social Scientists in Taiwan," 274.

14. Sarah Robbins, Debra Engel, and Christina Kulp, "How Unique Are Our Users? Comparing Responses Regarding the Information-Seeking Habits of Engineering Faculty," College and Research Libraries 72, no. 6 (2011): 515-32.

15. “U.S. News \& World Report: Education," available online at www.usnews.com/education [accessed 2 August 2010].

16. Wang, "Scholarly Journal Use and Reading Behavior of Social Scientists in Taiwan," 274.

17. Schonfeld and Housewright, Faculty Survey 2009, 5.

18. Maughan, "Library Resources and Services," 364. 


\section{ANNUAL REVIEWS}

Celebrating 80 Years of Publishing Excellence

Annual Reviews intelligently synthesizes critical literature in the Biomedical, Life, Physical, and Social Sciences, including Economics. Our editors and authors are premier researchers in their fields. Your patrons can rely on Annual Reviews to assess the available research and deliver the ideas that matter, to cut out the noise, and to meet their research needs efficiently.

\section{ANNUAL REVIEWS AVAILABLE ON MOBILE DEVICES. USERS CAN NOW:}

- Connect to library resources

- Browse journals and articles

- Search journals by keyword, author or title

- View abstracts

- Read full-text articles (personal or institutional subscription required)

- Read forthcoming articles (personal or institutional subscription required)

- View and search references and related links

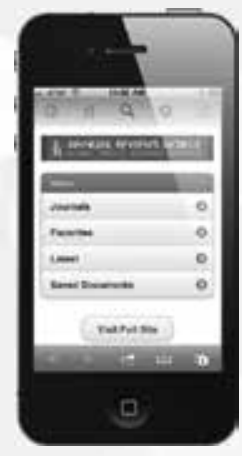

Visit www.annualreviews.org from a mobile device to learn more.

\section{SECURE ACCESS FOR YOUR PATRONS TODAY.}

Visit www.annualreviews.org or email sales@annualreviews.org.

\section{NEW JOURNAL NOW AVAILABLE:}

ANNUAL REVIEW OF ANIMAL BIOSCIENCES

Complimentary online access to the first volume will be available for the first year.

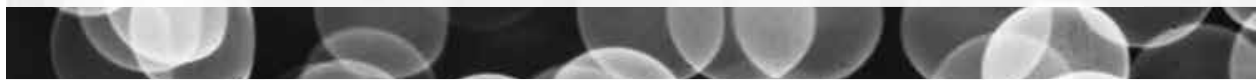

